\title{
Phrasal Phonology in Copperbelt Bemba
}

\author{
Nancy C. Kula and Lee Bickmore
}

\section{Introduction}

The goal of this paper is threefold: firstly to provide a detailed description and analysis of tonal spreading rules at the phrasal level in Copperbelt Bemba (CB); secondly to demonstrate a novel rule interaction in phrasal phonology that involves mutually-feeding iterative rules and how this can be formalized within Optimality Theory; and finally to consider the phonology-syntax mapping in CB and evaluate how well current prosodic correspondence theories - here ALIGN/WRAPXP and Match Theory - account for the prosodic constituent structure in $\mathrm{CB}$.

Building on earlier work conducted on CB tonology (Bickmore \& Kula 2013) two High tone spreading patterns will be central to the discussion of phrasal phonology in CB, namely Bounded Spreading and Unbounded Spreading. The characterisation of phonological phrases is crucial in accounting for these spreading patterns. The paper will examine High tone spreading within a series of single-word phonological phrases occurring in particular syntactic contexts where it is observed that a single High tone in the initial phonological phrase can surface on each lexically toneless syllable of subsequent phonological phrases. We present the basic tone patterns in section 2 and show in section 3 that a rule-based approached is forced to analyse the longdistance spreading patterns as involving mutually-feeding iterative rule interaction. In section 4 we present an alternative OT account of the facts which relies on a CRISP EDGE constraint that makes reference to juncture effects. Section 5 provides a discussion of whether constraints requiring the juncture of two smaller domains to be contained within a larger one are necessary and what the implications of an alternative formulation might be, at least for the present set of data. Finally section 6 provides some concluding remarks.

\section{Unbounded and Bounded High Spreading}

Following Bickmore and Kula (2013) we can identify two main High tone spreading processes within words in $\mathrm{CB}$, namely, Unbounded and Bounded spreading. Unbounded rightward $\mathrm{H}$ spreading targets the rightmost High tone in a phrase-final word (where "phrase" will be made more precise below in section 3) spreading it to the end of the word. We will show that Unbounded Spreading applies only within a word and not across words. Example (1) below illustrates Unbounded Spreading in CB with the source/lexical H tone on the subject marker (1a-b), the pre-prefix (1c), the TAM marker (1d) or on the first syllable of the verb stem (1e). In all cases the H spreads to the word-final TBU. (Underlying forms are shown in the rightmost column). ${ }^{1}$

\section{(1) Unbounded Spreading}
a. bá-ká-fík-á
'they will arrive'
/bá-ka-fik-a/
b. bá-ká-mú-lóóndólól-á
'they will introduce him/her'
/bá-ka-mu-londolol-a/ ${ }^{2}$
c. ú-kú-lóóndólól-á
'to introduce'
/ú-ku-londolol-a/
d. tù-léé-mú-lóóndólól-á
'we are introducing him/her'
/tu-lée-mu-londolol-a/
e. tù-kà-páápáátík-á
'we will flatten'
/tu-ka-páapaatik-a/

\footnotetext{
${ }^{1}$ The data presented in this paper come mainly from the first author, a native speaker of Copperbelt Bemba. Other speakers of CB have also been consulted for which we thank Honoria Mutale and Moses Nkandu.

${ }^{2}$ As in many Bantu languages, Bemba exhibits a demorification process whereby an underlying pre-consonantal nasal transfers its mora to the preceding vowel, rending it long.
} 
Unbounded Spreading occurs only if it can reach the word-final TBU. Bounded spreading, on the other hand, spreads a $\mathrm{H}$ in ternary fashion in $\mathrm{CB}$ if the word-final TBU already has a $\mathrm{H}$ or if the word undergoing $\mathrm{H}$ spreading is not phrase final. Bounded ternary spreading is shown in (2).

(2) Bounded Spreading

a. tà-tú-lúk-íl-èèné

b. bá-lóóndólòl-é

c. bá-ká-pát-à=kó

d. bá-mú-lúk-ìl-à=kó

$\begin{array}{ll}\text { 'we didn't weave for each other' } & \text { /ta-tú-luk-il-an-ilé/ } \\ \text { 'let them introduce' } & \text { /bá-londolol-é/ } \\ \text { 'they will hate (loc.)' } & \text { /bá-ka-pat-a=kó/ } \\ \text { 'they weave for him (loc.)' } & \text { /bá-mu-luk-il-a=kó/ }\end{array}$

In the examples above, the first lexical $\mathrm{H}$ in the word does not undergo Unbounded Spreading as it cannot reach the final TBU of the word due to another $\mathrm{H}$ already there. It undergoes ternary spreading instead. In $(2 \mathrm{a}-\mathrm{b})$ there is a Melodic High realized on the word-final TBU that blocks Unbounded spreading. ${ }^{3}$ In examples $(2 \mathrm{c}-\mathrm{d})$ the verb is followed by the locative enclitic kó. ${ }^{4}$

The examples below in (3) show that a High tone does not undergo Unbounded Spreading across a word boundary to the end of a phrase, demonstrating that Unbounded Spreading is restricted to words.
(3) a. tù-kà-lásh-íl-à Kòòmbè
'they will hit for Kombe'
/tu-ka-lás-il-a Kombe/
b. bá-ká-sálùl-à bwì̀nò
'they will fry well'
/bá-ka-salul-a buino/
c. ù-kú-lúk-ìl-à Kòòmbè
'to weave for Kombe'
/ú-ku-luk-il-a Kombe/

In these cases the $\mathrm{H}$ in the first word will not undergo Unbounded Spreading to the end of the phrase even though all subsequent TBUs within the phrase are toneless. This is because while Unbounded Spreading always targets the final TBU of the phrase, it applies only within a word, never crossing a word boundary. As seen, in both cases the $\mathrm{H}$ undergoes Bounded Spreading instead. In (3c) the $\mathrm{H}$ on the preprefix undergoes ternary spreading, but there is a subsequent tone rule which delinks a $\mathrm{H}$ from a word-initial onsetless syllable after it has undergone ternary spreading. The application of Unbounded Spreading can be characterized as follows:

\section{Unbounded Spreading:}

The rightmost $\mathrm{H}$ in a word will undergo Unbounded Spreading to the end of that word if 1) the final TBU of the word in question is toneless and 2) if the word is phrase-final. I.e. it applies to the rightmost $\mathrm{H}$ in a phrase-final word.

The examples below show that a $\mathrm{H}$ tone on a word-final TBU will ultimately spread to the final TBU of a following toneless word.
a. tù-kà-ly-á Chítúúndú
b. lùk-á bwínó
'we will eat Chitundu'
'weave well!'

/tu-ka-lí-a Chitundu/
/luk-á buino/

While it might seem, prima facie, that the $\mathrm{H}$ at the end of the first word is spreading in an unbounded fashion to the end of the phrase, this is actually not the case. We analyze these forms as undergoing two tone rules. The first is Inter-Word Doubling, which spreads a word-final H onto the initial TBU of a following word. This then feeds Unbounded Spreading, which then spreads the H, now on the initial TBU of the second word, to

\footnotetext{
${ }^{3}$ Bemba like most Bantu languages has both lexical $\mathrm{H}$ tones (associated underlyingly to various morphemes) as well as Melodic High $(\mathrm{MH})$ tones, contributed by various TAMs. In this regard, TAMs can be divided into four MH types: those with (i) no $\mathrm{MH}$; (ii) $\mathrm{MH}$ realized on the final vowel; (iii) MH realized on all TBUs from the pen-initial syllable up to and including the final vowel; and (iv) $\mathrm{MH}$ on the second syllable of the verb stem. See Bickmore \& Kula (2013) for detailed discussion.

${ }^{4}$ The ending /-ko/ is treated as an enclitic on the verb in the Bantu literature (see Marten and Kula 2014). Phonologically, based on its tonal interaction with the verb stem where it patterns with H-toned suffixes, it is part of the same prosodic word as the verb.
} 
the end of the second word, which is the final one in the phrase. We see that Inter-Word Doubling is an independently attested process in the examples below.
a. ì-cí-páàpá cí-sùmá
b. ù-lú-táàndá lú-sùmá
c. pàt-á Kápèèmbwá
d. bélééng-èl-á Kápèèmbwá

'good rind'

/í-ci-paapá ci-sumá/

'good star'

'hate Kapembwa!'

'read for Kapembwa!'

/ú-lu-tandá lu-sumá/

/pat-á Kapembuá/

/béleng-il-á Kapembuá /

The examples above illustrate that a word-final $\mathrm{H}$ tone will spread to the initial TBU of the following word. However, since the final TBU of the second word has a $\mathrm{H}$ on it, the $\mathrm{H}$ which has spread onto the initial TBU of the second word cannot then undergo Unbounded Spreading. The rule of Inter-Word Doubling is thus defined as follows:

\section{Inter-Word Doubling:}

A High on the final TBU of one word spreads onto the initial TBU of a following word.

Next, let us consider the examples below, where an underlying $\mathrm{H}$ on the penult spreads into a following word, and subsequently spreads to the end of the following word if it is completely toneless.
a. tù-kà-lás-á Kápèèmbwá
'we will hit Kapembwa'
b. tù-kà-lás-á Chítúúndú
'we will hit Chitundu'

/tu-ka-lás-a Kapembuá/

/tu-ka-lás-a Chitundu/

In both examples, we argue that the $\mathrm{H}$ on the penult in the first word (as it is not the rightmost $\mathrm{H}$ of a phrase-final word) will undergo Bounded Spreading. Since the H is then linked to the word-final TBU, it will subsequently undergo Inter-Word Doubling onto the initial TBU of the second word. In (8b) where the following word is completely toneless, Unbounded Spreading will then apply, which spreads the $\mathrm{H}$ to the wordfinal TBU of the second word, which is the end of the phrase.

Thus, to generalize thus far, a High tone will ultimately spread to the end of a phrase in three cases: 1) if it is underlyingly in a phrase-final word followed by a string of toneless TBUs all the way to the end of that word (1),2) if it originates on the final TBU of a word followed by a completely toneless word (in the same phrase) (5) or 3 ) if it originates on the penultimate TBU of a word where the ultima is toneless and there is a following completely toneless word in the same phrase $(8 b)$.

If the $\mathrm{H}$ in the first word is in a pre-penultimate position (as in (3) above) then the $\mathrm{H}$ will not in fact spread to the end of the second word, but instead undergoes Bounded Spreading. Given that, one might wonder why the $\mathrm{H}$ in example (3a), on the antepenult, did not spread to the end of the word given that we have characterized Bounded Spreading in $\mathrm{CB}$ as ternary. To account for this, we must examine the process of Bounded Spreading in CB more closely.

Bickmore \& Kula (2013) argue that the ternary spreading pattern is formally accomplished by a sequence of two distinct rules - distinct in that they are motivated by and subject to different constraints, but related because they have a dependency relation; the application of the second rule requires the first. The two rules are summarized below:

(9) Bounded Spreading (two rules):

a. High Doubling: spreads a $\mathrm{H}$ onto the following mora; not subject to the OCP, and can target a wordfinal TBU

b. Secondary High Doubling: continues to spread a $\mathrm{H}$ onto the first mora of the following syllable; subject to the OCP, and will never spread a $\mathrm{H}$ onto a word-final TBU. 
The two rules can be distinguished by their OCP requirements and their ability to spread a $\mathrm{H}$ onto a word-final TBU. High Doubling (HD) will spread a $\mathrm{H}$ onto a following TBU, even when that produces an OCP violation, as can be seen in the examples in (10). These derived OCP violations result in a phonetic downstep. ${ }^{5}$ In each case the rightmost lexical or Melodic $\mathrm{H}$ is downstepped after HD creates $\mathrm{H}$ adjacency with a following lexical H. Example (10a) (like (8b))) demonstrates that HD can target word-final TBUs.

\section{(10) Downstep in CB}
a. bá-ká-'lás-á sáàná
b. ú-kú-'léét-él-á
c. kálí p-á
'they will hit a lot'
'to bring for'
'be angry!'
/bá-ka-lás-a sáaná/
/ú-ku-léet-il-a/
/kálip-á/

The application of Secondary High Doubling (SHD) contrasts with that of HD, with additional $\mathrm{H}$ spreading blocked to avoid an OCP violation as the examples in (11) show. In these cases the leftmost $\mathrm{H}$ is followed by another $\mathrm{H}$ within the word which blocks ternary spread so as to avoid an OCP violation. These data demonstrate that the OCP does not in fact apply across the board to all tone spreading rules, but rather constrains certain spreading processes and not others.
(11) a. bá-ká-mù-lás-á
b. tú-lúk-ill-é
c. kálíp-ìl-á

\author{
'they will hit him/her' \\ 'that we weave for' \\ 'be angry at!'
}

/bá-ka-mu-lás-a/
/tú-luk-il-é/
/kálip-il-á/

Below, we provide derivations for (2c), (10b), and (11a):
a. bá-ka-pat-a=kó
b. ú-ku-léet-el-a
c. bá-ka-mu-lás-a
U.R.
bá-ká-pat-a=kó
bá-ká-pát-a=kó
ú-kú-'léét-el-a
bá-ká-mu-lás-á
High Doubling
$\mathrm{n} / \mathrm{a}$
ú-kú-'léét-él-a
blocked by OCP
Secondary High Doubling
$\mathrm{n} / \mathrm{a}$

The second distinction between HD and SHD is that the latter never spreads a High onto a word-final TBU, even in cases where the following word begins with a Low-toned TBU. This is illustrated below:

(13) a. tù-kà-lásh-íl-à kà-fúúnd-ísh-á

b. tù-kà-bá-pát-à bwì̀nò 'we will hit for the teacher'

'we will hate them well' /tu-ka-lás-il-a ka-fúnd-ish-a/

/tu-ka-bá-pat-a buino/

In the examples above the rightmost $\mathrm{H}$ in the first word in each case only spreads once onto the following TBU and does not spread to the final vowel. This, then, serves to explain why only a $\mathrm{H}$ on the penult or ultima will ultimately spread into a following word. A $\mathrm{H}$ in a pre-penult position will not spread into the following word since it will never spread to the final TBU of the word that it is in. If it is on a pre-penult TBU (of a non-phrasefinal word) then it will undergo ternary spreading. When the $\mathrm{H}$ is in pre-antepenult position, full ternary spreading will only reach a pre-ultima TBU, and if the $\mathrm{H}$ is in ante-penultimate position, it will not reach the ultima due to a prohibition on SHD spreading a $\mathrm{H}$ to a word-final TBU.

Having now examined HD and SHD in some detail, it is important to highlight that each of these differ

\footnotetext{
${ }^{5}$ Whether the downsteps are triggered by a floating $\mathrm{L}$ tone, or are just the result of two adjacent TBUs linked to distinct Hs (adopting Odden's (1986) proposal for Kishambaa), is somewhat orthogonal to our concerns here. What is important, however, is to note that downsteps only result from the effects of HD, as well as Inter-Word Doubling (cùùlá mú-'kúlú 'big frog' </cuulá mu-kúlu/). In addition, downsteps occur only word-internally, never across a word boundary. No downstep results from underlyingly adjacent Hs. E.g. /bá-ka-yá-lás-il-a/ > bá-ká-'yá-lásh-íl-á 'they will aim at (throw at) for them', where no downstep is found between [yá] and [lásh]. If $\mathrm{L}$ is underspecified then one must assume underlyingly adjacent Hs fuse.
} 
from Inter-Word Doubling. One might, for instance, ask whether the spreading across words exemplified in (6) and (8) might be the result of HD. The first indication that it is not is that we have seen in examples such as (2) that HD feeds SHD, yet this is not attested in (6c-d). Second and most importantly, we see in (8) that HD must be able to feed Inter-Word Doubling (IWD).

To illustrate the rule interaction involved in generating these forms, we provide derivations below for $(6 c),(8 a)$ and $(8 b)$. The relevant rule applying at each stage is given on the right hand side.

$\begin{array}{llll}\text { a. pat-á Kapeembwá } & \text { b. tu-ka-lás-a Kapeembwá c. tu-ka-lás-a Chituundu } & \text { U.R. } \\ \text { n/a } & \text { tu-ka-lás-á Kapeembwá } & \text { tu-ka-lás-á Chituundu } & \text { High Doubling } \\ \text { n/a } & \text { n/a } & \text { n/a } & \text { Secondary H Doubling } \\ \text { pat-á Kápeembwá } & \text { tu-ka-lás-á Kápeembwá } & \text { tu-ka-lás-á Chítuundu } & \text { Inter-word Doubling } \\ \text { n/a } & \text { n/a } & \text { tu-ka-lás-á Chítúúndú } & \text { Unbounded Spread }\end{array}$

In (14a) neither HD nor SHD applies as these are both word-level rules. IWD applies spreading the H onto the initial TBU of the following word. Unbounded Spreading does not continue to spread that $\mathrm{H}$ since there is a subsequent $\mathrm{H}$ in the second word. In (14b), HD applies to spread the root $\mathrm{H}$ onto the word-final TBU. SHD does not apply as it is strictly a word-level process. IWD then applies to spread the $\mathrm{H}$ onto the initial TBU of the following word. In (14c), HD applies, which feeds IWD spreading the H onto the initial TBU of the following word. Since no other H follows, Unbounded Spreading then applies, spreading the H to the ultima of the second word.

We have shown that Unbounded Spreading only applies to the rightmost $\mathrm{H}$ in a phrase-final word. Unbounded Spreading did not apply in (14a-b) because the High was not the rightmost one in the word. But we predict that it should also fail to apply in the case where yet another word follows in the same phrase, even if the $\mathrm{H}$ is the rightmost $\mathrm{H}$ within the word that contains it. That this is true is illustrated below where the postverbal object nouns are modified by an adjective.

(15) a. pàt-á cáàngà mù-sùmá

'hate the good bush-baby!' /pat-á caanga mu-sumá/

b. tù-kà-ly-á kálùkùlùkù mù-sùmá 'we will eat the good turkey’/tu-ka-lí-a kalukuluku mu-sumá/

In each case in (15) the $\mathrm{H}$ in the first word has spread onto the initial mora of the following word via IWD. The question then becomes whether it will continue to spread via Unbounded Spreading. It does not. This is because the $\mathrm{H}$, now on the initial mora of the second word, does not match the structural description of Unbounded Spreading, which requires the $\mathrm{H}$ to be the "rightmost $\mathrm{H}$ of a phrase-final word." Since another word follows in the phrase, no additional spreading occurs even though all the following morae in that second word are toneless.

We will now look at the spreading processes discussed above with the goal of better understanding the contexts in which they apply and specifically defining the syntactic contexts which have an effect on $\mathrm{H}$ tone spreading in CB.

\section{Phrasal Domains in Copperbelt Bemba}

\subsection{Theories of Prosodic Phrasing}

We assume that phrasal phonological processes make reference to prosodic constituents, which, in turn, are determined by various aspects of the syntax. As a starting point below we list the four central prosodic domains we assume following the work of Nespor and Vogel (1986) and Selkirk (1986): 
(16) a. Phonological Word

b. Phonological Phrase

c. Intonational Phrase

d. Utterance

These domains are motivated in particular languages when a phonological process applies within certain groups of words but not others. In Copperbelt Bemba, for example, we have claimed above that Unbounded Spreading affects the rightmost $\mathrm{H}$ in a phrase-final word. We must now describe and formalize exactly what this phrase is. In the discussion that follows we make reference to two current approaches to prosodic phrasing. ${ }^{6}$ The first is the "Align XP" approach as presented in Selkirk $(1986,1995)$, where prosodic phrase edges are found at either the left or right edges of maximal projections. As part of this first approach we include Truckenbrodt's (1999) proposal which presents WRAP $(\mathrm{XP}, \varphi)$, a constraint which demands that each syntactic maximal projection be contained within a phonological phrase (p-phrase). Thus, a verb phrase with two objects [V [NP][NP]], without WRAP XP or where WRAP XP is lowly ranked would be prosodically phrased (where alignment is to the right) as in (17a), whereas when WrAP XP outranks ALIGN XP it would phrase as (17b). And whereas both $(17 \mathrm{a}, \mathrm{b})$ respect the Strict Layer Hypothesis, the introduction of a NON-RECURSIVITY constraint allows for additional phrasings. When WRAP XP and ALIGN XP outrank NON-RECURSIVITY, then the phrasing would be as in (17c).

Possible prosodic phrasings of $[\mathrm{V}[\mathrm{NP}][\mathrm{NP}]]_{\mathrm{VP}}$ with Align XP/Wrap XP plus Nonrecursivity
a. $(\mathrm{V} \mathrm{NP})_{\mathrm{P}}(\mathrm{NP})_{\mathrm{P}}$
b. $(\mathrm{V} \text { NP NP })_{\mathrm{P}}$
c. $\left((\mathrm{V} N P)_{\mathrm{P}}(\mathrm{NP})_{\mathrm{P}}\right)_{\mathrm{P}}$

The second approach to prosodic phrasing that we will reference is Selkirk's (2011) Match Theory. This theory proposes that syntactic constituents are matched (on both the right and left edges) by a corresponding prosodic constituent. Specifically, a syntactic clause is matched by an intonational phrase, a syntactic phrase by a phonological phrase, and a syntactic word by a phonological word. In brief, given these assumptions, assuming no higher ranked constraints intervene, Match Theory will generate only the prosodic phrasing shown below in (18). Selkirk therefore argues that Match Theory is more restrictive than ALIGN XP + WRAP XP. With these brief descriptions as background, let us focus on an examination of the Copperbelt Bemba phrasal patterns.

(18) Possible prosodic phrasings of [V [NP][NP] $]_{\mathrm{VP}}$ with Match XP and no Nonrecurisivity constraint

$$
\left(\mathrm{V}(\mathrm{NP})_{\mathrm{P}}(\mathrm{NP})_{\mathrm{P}}\right)_{\mathrm{P}}
$$

\subsection{Motivating and Defining Phonological Phrases in CB}

The phrases that we have examined thus far have contained words with a fairly close syntactic relationship to each other: e.g. Verb-Adverb (2e), (10a), (13b); Verb-Object (3a,c), (5a), (6c-d), (8) (13a), (15); and NounAdjective (6a-b). Similar to what has been shown for a variety of other languages (see inter alia Dehe et al. 2010, Inkelas \& Zec 1990, McHugh 1990, Nespor \& Vogel 1986, Selkirk 1986 and Vincent \& Mycock 2010) we propose that these sequences of words belong to the same phonological phrase (p-phrase). In each case the first word is not in phrase-final position and the rightmost $\mathrm{H}$ in that word never undergoes Unbounded Spreading. Apart from the fact that the words in question have a close syntactic relationship, we will show that there is also strong phonological evidence supporting this phrasing.

\footnotetext{
${ }^{6}$ We are aware of Direct approaches to the interface that take no recourse to prosodic constituents but do not include these in the current discussion. See Scheer (2012), Kula (2007), Kaisse (1985), for some discussion.
} 
In all of the Verb-Adverb, Verb-Object and Noun-Adjective sequences given above, comprising phonological phrases, $\mathrm{H}$ spreading within the first word of the phrase is bounded. This contrasts with Unbounded Spreading which we see is exhibited when the word is phrase-final (1). The question then arises: what happens to the rightmost $\mathrm{H}$ in one word when it is followed by another word that is not in the same phonological phrase (i.e. where the two words have a less close syntactic relationship)? To answer this, let us examine the case where the two words consist of a Subject-Verb sequence. ${ }^{7}$ As seen below, in this case the rightmost High in the first word undergoes Unbounded Spreading rather than Bounded Spreading, even though another word follows.

(19) a. (ì-m-bálámínwé) (shí-ká-'pón-á)

b. (à-bá-límí) (bá-ká-'léét-á) 'the rings will fall'

'the farmers will bring' /í-m-balaminue shí-ka-pón-a/

/á-ba-limi bá-ka-léet-a/

As can be seen, the (sole, and therefore rightmost) $H$ in the first word in each case undergoes Unbounded Spreading, even though it is followed by another word. These examples can be accounted for straightforwardly if we assume that Unbounded Spreading reflects the fact that the word is in final position within a phonological phrase. The verb in (19) constitutes its own phonological phrase and exhibits Unbounded Spreading of its rightmost $\mathrm{H}$. We assume these two phonological phrases combine to form an intonational phrase and ultimately an utterance.

We have proposed that in cases of a verb and following object the verb is not in phrase-final position, while a subject is as it constitutes a separate phonological phrase. Given the contrastive behavior of examples in (2), (13) and (6), on the one hand (where the rightmost $\mathrm{H}$ in the first word undergoes Bounded Spreading) with those in (19) on the other (where the rightmost $\mathrm{H}$ in the first, non-phrase-final word undergoes Unbounded Spreading), we now examine a fuller set of CB examples to determine which syntactic contexts behave like the former and which behave like the latter. In each case the presence of Unbounded Spreading will diagnose a following right edge of a phonological phrase and Bounded Spreading will indicate the absence of a following right edge of a phonological phrase. We will then return to the question as to whether ALIGN/WRAP XP or Match Theory better represents the prosodic phrasing necessary to account for the presence or absence of Unbounded Spreading.

In each of the examples in (20)-(23) below, the rightmost $\mathrm{H}$ in the first word undergoes Bounded (ternary) Spreading, and is therefore diagnosed as not being at the end of a phonological phrase. In each case we show the first and second word as belonging to a phonological phrase that comprises both words, i.e. $\left(\mathrm{W}_{1}-\right.$ $\mathrm{W}_{2}$ ). While this is predicted by both Align/Wrap as well as Match Theory, we note here that the latter theory also predicts that the second word, being a syntactic phrase, constitutes its own phonological phrase, i.e. $\left(\mathrm{W}_{1}-\right.$ $\left.\left(\mathrm{W}_{2}\right)\right)^{8}$

(20) (Verb - Object)
a. (bá-ká-lúk-ìl-à Kòòmbè)
b. (ú-kú-'bélééng-él-à mùlámù)
'they will weave for Kombe'
'to read for the bro-in-law'
/bá-ka-luk-il-a Kombe/
/ú-ku-béleng-el-a mulámu/

\footnotetext{
${ }^{7}$ Bantu languages show subject-verb agreement with the verb carrying a subject concord depending on the Noun Class of the subject noun. Bantu languages are therefore pro-drop languages and it has been argued on this basis that perhaps subjects are topics in Bantu. See for some discussion Bresnan \& Mchombo (1987), Morimoto (2005), among others.

${ }^{8}$ We assume the following syntactic structure for the examples in (20-23 and 26-30). Numbers below refer to example numbers in
} text.

20: $(\text { Verb Object) })_{\mathrm{VP}}$

21: (Verb Adverb) $\mathrm{VP}$

22: (Noun Adjective) $)_{D P}$

23: (Noun Possessive) $)_{D P}$

24: $(\text { Subject })_{\mathrm{DP}}(\text { Verb })_{\mathrm{VP}}$
26: $\left((\text { Verb Object })_{\mathrm{VP}} \text { Object }\right)_{\mathrm{VP}}$

27: $\left((\mathrm{NP})_{\mathrm{DP}}(\mathrm{Conj}=\mathrm{NP})_{\mathrm{DP}}\right)_{\mathrm{DP}}$

28: $(\mathrm{NP}-\mathrm{Obj})_{\mathrm{DP}}(\mathrm{Verb})_{\mathrm{VP}}$

29: $(\text { Verb-OM })_{\mathrm{VP}}(\text { Object })_{\mathrm{DP}}$

30: $(\text { Verb })_{\mathrm{VP}}(\mathrm{NP}-\text { Subject })_{\mathrm{DP}}$ 
(21) (Verb - Adverb)
a. (bá-ká-sálùl-à bwì̀nò)
'they will fry well'
/bá-ka-salul-a buino/
b. (tù-léé-mú-shìik-ìl-à bwì̀nò)
'we are burying for him well'
/tu-lée-mu-shiik-il-a buino/
c. (úkú-'bélééng-él-àn-à sáàná)
'to read for each other a lot'
/úku-béleng-el-an-a sáaná/

(22) (Noun - Adjective)
a. (ì-m-bálámìnwè shì-sùmá)
'good rings'
/í-m-balaminue shi-sumá/
b. (ùmú-súkùpàlà ù-sùmá)
'good bottle'
/ú-mu-sukupala u-sumá/
c. (úkú-'táláántáànt-à kù-kúlú)
'the big stumbling'
/ú-ku-tálantant-a ku-kúlu/

(23) (Noun - Possessive)
a. (ì-m-bálámìnwè y-òòbè)
'your ring'
/í-m-balaminue i-obe/
b. (ìcí-sótè c-ààndì)
'my hat'
/í-ci-sote ci-andi/

The examples above contrast with those below, where the rightmost $\mathrm{H}$ in the second to last word undergoes Unbounded Spreading. We account for this by positing that this word is in phonological phrase-final position and the following word begins a new phonological phrase. In cases where the first phonological phrase consists of two words (25)-(26) Unbounded Spreading is observed as expected on the p-phrase final word (i.e. the second word) of the first phonological phrase.

(24) (Subject) (Verb)

$(\operatorname{see}(19))$

(25) (Verb Object) (Adverb)

a. (ùkú-pát-è è-m-bálámínwé) (sáàná) 'to hate the rings a lot' /ú-ku-pat-a í-m-balaminue sáaná/

b. (bá-ká-pát-è è-m-péléémbé) (sáàná) 'they will hate the antelopes a lot' /bá-ka-pat-a í-m-pelembe sáanál

(26) (Verb Object) (Object)

a. (ùkú-shíik-ìl-è è-m-péléémbé) (éfíí-ntú) /ú-ku-shiik-il-a í-m-pelembe í-fí-ntu/

b. (bá-ká-shíik-ìl òò-mú-límí) (Búúpè) /bá-ka-shiik-il-a ú-mu-limi Búupe/

(27)
(NP) $($ Conj $=\mathrm{NP})$
Conjoined NPs ${ }^{9}$

'to bury the things for the antelope'

'they will bury Bupe for the farmer'
a. (ì-m-bálámínwé) (ná=Mùbààngá)
b. (ì-m-péléémbé) (ná=cùùlá)
'the ring and Mubanga'
/í-n-balaminue na Mubangá/
'the antelope and the frog' /í-n-pelembe na cuulá/

\footnotetext{
9 The 'conjunction' marker na= is a proclitc that treats the following noun as prosodic host. It functions as a preposition (with) which can also be used to mean 'and' as in this context. For this reason we treat the (na=Mubanga) constituent as a Prepositional Phrase that is a complement to the preceding NP and hence the phrasing assumed here.
} 

a. (ùmú-límí) (bá-lá-pát-á)
'the farmer they hate'
/úmu-limi bá-la-pat-a/
b. (ì-m-bálámínwé) (bá-ká-shíik-á)
'the rings they will bury'
/í-m-balaminue bá-ka-shiik-a/

(29) (Verb with OM) (Object) ${ }^{11}$
a. (ùkú-mú-'bélééng-él-ó) (ó-mú-límí)
'to read to the farmer'
/ú-ku-mu-béleng-el-a ú-mu-limi/
b. (tù-léé-mú-lóóndólól-á) (Búúpè)
'we are introducing Bupe' /tu-lée-mu-londolol-a Búupe/
c. (bá-ká-mú-lóóndólól-á) (shíngáángà) 'they will introduce the doctor'
/bá-ka-mu-londolol-a shínganga/

(30)
(Verb) (NP-subject)
Post-posed Subject
a. (bá-ká-'páápáátík-íl-án-á) (ábá-límí) /bá-ka-páapaatik-il-an-a á-ba-limi/
b. (bá-léé-lím-á) (ábá-límí) /bá-lée-lim-a á-ba-limi/

'they will flatten for each other, the farmers that is'

'they are farming, the farmers that is'

Based on the patterns of Bounded and Unbounded Spreading in the above examples we are able to determine the presence vs. absence of a right edge of a phonological phrase between the two words in question. ${ }^{12} \mathrm{We}$ conclude this section by noting that both Align/Wrap and Match Theory clearly distinguish the prosodic phrasing in the relevant two word sequences in (20)-(23) from those in (24)-(30). Both theories predict that the first word in these sequences is not phonological phrase-final in the former, but is in the latter. We note again that in (20)-(23) Match Theory also predicts the second word in sequence constitutes its own (recursive) phonological phrase. We conclude then that the prosodic phrasing necessary to account for the $\mathrm{H}$ tone spreading in Copperbelt Bemba is adequately established by both theories and thus the data does not decide between them.

\subsection{Mutually-feeding Spreading Rules}

Let us now examine some additional CB phrases. The examples in (27) reveal something interesting about the interaction between Inter-Word Doubling and Unbounded Spreading. The former rule was shown to feed the latter in (5). The $\mathrm{H}$ on the preprefix in the first noun in the examples in (27) undergoes Unbounded Spreading, as it is the rightmost $\mathrm{H}$ in a p-phrase final word. But as can be seen, that process then feeds Inter-Word Doubling, as the $\mathrm{H}$ then spreads onto the toneless proclitic conjunction $n a$, which is part of the following word. The interaction between these two rules is pushed even further in the examples below where IWD spreads onto a following completely toneless word, in which case Unbounded Spreading applies a second time.

\footnotetext{
${ }^{10}$ As noted these examples require a contrastive focus reading and are used in a context like 'the farmer they hate but the teacher not'.

${ }^{11}$ The Object Marker within the verb in Bantu is treated as pronominal with the following object no longer within the same clause as the verb and has been used (together with subject marking) as licensing the relatively free word order in Bantu (see Bresnan \& Mchombo 1987, among others) making Bantu languages discourse configurational (Morimoto 2005). Similar patterns are seen in a number of Bantu languages including Cilungu (Bickmore 2007). Object marking in Bemba is severely restricted and is generally ungrammatical with non-animate objects (Marten et al. 2007, Marten \& Kula 2012).

12 Functionally, the presence of Bounded vs. Unbounded Spreading of the rightmost H of W1 in any W1-W2 sequence helps to identify whether W1 and W2 belong to the same p-phrase or to different ones. This diagnostic always works when the H in W1 is in pre-penult position. (Recall from the examples in (8) that an antepenultimate $\mathrm{H}$ in a phrase-final word undergoes binary rather than ternary spreading.) When the H in W1 is on the penult or ultima, then the H, via High Doubling and/or Inter-Word Doubling, will spread into the next word rendering the sequence ambiguous as to whether there is a p-phrase boundary between the two words or not.
} 
(31) a. (bá-ká-shíik-ìl òò-mú-límí) (Chítúúndú) 'they will bury Chitundu for the farmer' /bá-ka-shiik-il-a ú-mu-limi Chitundu/

b. (ì-m-péléémbé) (ná=cáángá) 'the antelope and the bush-baby'

/í-n-pelembe na canga/

In these examples, the $\mathrm{H}$ on the preprefix in the $\mathrm{p}$-phrase final word in the first $\mathrm{p}$-phrase spreads to the end of the word via Unbounded Spreading as it is the rightmost $\mathrm{H}$ in a p-phrase-final word. That $\mathrm{H}$ then undergoes Inter-Word Doubling (as it did in (27)). Then, since the H, now on the first mora of the final word, is again the rightmost $\mathrm{H}$ in a p-phrase-final word, it undergoes Unbounded Spreading yet again.

Under a rule based approach we conclude that the rules of Inter-Word Doubling and Unbounded Spreading are mutually feeding processes. It does not seem possible to accomplish the totality of the spreading in (27) or (31) with a single rule. Examples in (20)-(23) where the two words are not separated by the right edge of phonological phrase show that it is certainly not the case that a $\mathrm{H}$ spreads unboundedly through toneless syllables across word boundaries.

Under the assumption that these two rules are mutually-feeding and iterative, our analysis then predicts that in a sequence of $\mathrm{W}_{1} \mathrm{~W}_{2} \ldots \mathrm{W}_{\mathrm{n}}$, where a right $\mathrm{p}$-phrase edge follows each word in the sequence, that the rightmost $\mathrm{H}$ in $\mathrm{W}_{1}$ will ultimately spread to the very end of $\mathrm{W}_{\mathrm{n}}$. That this is true can be seen in the examples below:

(32) a. (Conjoined Subject) (Verb)

(íné) (ná=Chísáángá) (tú-ká-shíík-á) 'me and Chisanga will bury'

/íne na=Chisanga tu-ka-shiik-a/

b. (Verb-OM) (Object) (Object)

(bá-ká-mú-shíik-íl-á) (Chítúúndú) (cáángá)

/bá-ka-mu-shiik-il-a Chiuundu canga/

'they will bury the bush-baby for Chitundu'

c. (Verb-OM) (Object) (Adverb)

(bá-ká-mú-shíík-íl-á) (Chítúúndú) (bwínó)

/bá-ka-mu-shiik-il-a Chitundu buino/

'they will bury for Chitundu well'

d. (Verb-OM) (Object) (Object) (Adverb)

(bá-ká-mú-shíík-íl-á) (Chítúúndú) (cáángá) (bwínó) 'they will bury the bush-baby for C well'

/bá-ka-mu-shiik-il-a Chitundu canga buino/

In all the examples in (32) each word consists of its own phonological phrase indicated by the presence of Unbounded Spreading with the effect that three otherwise toneless constituents following the verb in (32d) surface with all $\mathrm{H}$ tone. A derivation of (32c) in a rule-based approach, detailing each step of the process and the rule interaction involved is given below.

(33) a. /bá-ka-mu-shiik-il-a Chitundu canga buino/

b. (bá-ká-mú-shíík-íl-á) (Chituundu) (caanga) (bwiino)

c. (bá-ká-mú-shíí-íl-á) (Chítuundu) (caanga) (bwiino)

d. (bá-ká-mú-shíík-íl-á) (Chítúúndú) (caanga) (bwiino)

e. (bá-ká-mú-shíík-íl-á) (Chítúúndú) (cáanga) (bwiino)
U.R.

Unbounded Spreading

IWD

Unbounded Spreading

IWD 
f. (bá-ká-mú-shíik-íl-á) (Chítúúndú) (cáángá) (bwiino)

g. (bá-ká-mú-shíik-íl-á) (Chítúúndú) (cáángá) (bwíino)

h. (bá-ká-mú-shíik-íl-á) (Chítúúndú) (cáángá) (bwiínó)
Unbounded Spreading

IWD

Unbounded Spreading

The underlying representation of the sentence, shown in (33a) contains a single $\mathrm{H}$ on the subject marker /bá-/, all the other TBUs in the sentence being toneless. Unbounded Spreading indicates that there is a phonological phrase boundary after each word. The three syntactic junctures, from left to right, were previously motivated in (29), (26) and (25), respectively. In (b) the H on the SM undergoes Unbounded Spreading as it is the rightmost $\mathrm{H}$ in a phrase-final word. In (c) we see that Inter-word Doubling has spread the $\mathrm{H}$ from the ultima of the first word onto the initial TBU of the following word. The $\mathrm{H}$ is now the rightmost one in the last (and only) word in its p-phrase and hence undergoes Unbounded Spreading again, shown in (d). This feeds InterWord Doubling (e), which feeds Unbounded Spreading (f), which again feeds IWD (g), which again feeds Unbounded Spreading (h). The final effect is that the $\mathrm{H}$ has ultimately spread over 12 syllables to the end of the utterance.

It is appropriate to again stress that this is not a process that simply spreads a $\mathrm{H}$ onto as many subsequent toneless syllables as possible. This can be clearly seen by contrasting the spreading behavior in (33), with that in (34) below, where the latter is the very same sentence, but without an object marker in the verb. Recall that the reason there was a p-phrase boundary between the first two words in (33) is due to the presence of an OM in the verb (as illustrated in (29)). If we remove the OM, then the verb and the following object will be part of the same p-phrase (as seen in (20)). This has drastic effects on the spreading of the $\mathrm{H}$, as seen below.

(34) (Verb-Object) (Object) (Adverb)

(bá-ká-shíik-ìl-à Chìtùùndù) (cààngà) (bwì̀nò)

/bá-ka-shiik-il-a Chitundu canga buino/

'they will bury the bush-baby for Chitundu well'

Even though the $\mathrm{H}$ on the SM /bá-/ is followed by all toneless TBUs, the H spreads only in a bounded fashion. This is because Unbounded Spreading only occurs if the $\mathrm{H}$ is the rightmost $\mathrm{H}$ in a p-phrase-final word. While that was true for the H on /bá-/ in (33), it is not the case in (34) since there is another word (Chituundu) following in the same p-phrase. As the Bounded Spreading does not spread the $\mathrm{H}$ to the final TBU of the word, the structural description of IWD is not met and hence the spreading stops. ${ }^{13} \mathrm{~A}$ second example, illustrating the same point, is given in (35) where the object noun is modified by an adjectival phrase.

\section{(Verb) (Noun-Adjective) \\ (bá-ká-mú-shík-á) (cáàngà mù-sùmá) \\ /bá-ka-mu-shiik-a canga mu-sumá/}

'they will bury the good bush-baby'

Here the $\mathrm{H}$ on the SM /bá-/ spreads to the ultima as it is the rightmost $\mathrm{H}$ in a p-phrase-final word. This then feeds IWD, which doubles the $\mathrm{H}$ onto the initial TBU of the following object. But while that $\mathrm{H}$ is now the rightmost one on the object, the object is not phrase-final, due to the following adjective which groups with it in the same p-phrase (as in (22)). Therefore no additional spreading occurs, even though the following four TBUs in the utterance are toneless. ${ }^{14}$

To conclude the descriptive analysis of the above examples, the full array of Copperbelt Bemba phrasal patterns can be accounted for within a rule-based framework by the interaction of three spreading processes: Bounded Spreading, Unbounded Spreading and Inter-Word Doubling. This analysis, however, demands that

\footnotetext{
${ }^{13}$ Note that the proposed analysis of phonological phrasing and the syntax-phonology mapping proposed for CB will in (35) place caanga 'bush baby' and bwiino 'well' into two separate p-phrases despite the absence of Unbounded Spreading. We take up this issue in section 5 .

${ }^{14}$ If the $\mathrm{OM} / \mathrm{mu}-/$ is removed from (36), all three words become part of the same p-phrase and no Unbounded Spreading is attested: (bá-ká-shíik-à cààngà mù-sùmá)
} 
Unbounded Spreading and Inter-Word Doubling be mutually feeding rules that apply iteratively in order to account for the full array of surface phrasal patterns. It is not evident to us how one could dispense with or complicate either of these rules such that an iterative application would not be necessary.

\section{An Optimality-Theoretic Analysis}

Having described the spreading patterns and shown that a rule-based approach requires a mutually feeding iterative rule interaction, we now turn to an OT analysis of the same patterns. We begin by accounting for Bounded Spreading at the prosodic word level, which, as described above, is generally ternary, as in (2), unless this would cause an OCP violation, in which case it is binary, as in (11). We motivate spreading by the constraint * MONOMORAIC HTS. ${ }^{15}$

\section{*MONOMORAIC HTS}

Assign a penalty to any monomoraic High Tone Span

This constraint will force spreading, but is satisfied with any amount of spreading. The penalty for spreading is $* \mathrm{H}$, given below. ${ }^{16}$

$* \mathrm{H}$

A penalty is assigned for each H-toned TBU in the output.

By ranking *MONOMORAIC HTS above ${ }^{*} \mathrm{H}$, we predict spreading to a single TBU - i.e. Doubling. ${ }^{17}$ But since spreading is optimally ternary in CB we need an additional constraint. While this could be accomplished in different ways, we will assume a *BINARY HTS constraint, that forces additional spreading.

\section{*BINARY HTS}

Assign a penalty to any HTS of exactly two morae

The final constraint needed here is the OCP, since, as shown in (10) and (11), it has differential effects on binary vs. ternary spreading.

\footnotetext{
${ }^{15}$ There have been a number of proposals on how to account for Bounded Spreading in OT, of which this is one. Others include LOCAL (Yip 2002), EXTEND (Bickmore 1999), and SPAN BINARITY (McCarthy 2004).

${ }^{16}$ As formalized here, ${ }^{*} \mathrm{H}$ would be categorized as a markedness constraint. It would also be possible to analyse the penalty of spreading as a faithfulness constraint of the IDENT variety, but one cannot conflate the penalty for an input toneless TBU becoming $\mathrm{H}$, with an input H TBU becoming toneless, as the latter is a much more severe violation in CB. In this paper, we will assume IDENT (H), undominated in all our examples, is used to penalize an input $\mathrm{H}$ which surfaces as toneless (e.g. through the delinking of a $\mathrm{H}$ autosegment). This, e.g., will prevent any kind of $\mathrm{H}$ tone shift. DEP-H, preventing the insertion of new $\mathrm{H}$ autosegments, and MAX-H, preventing their deletion, are also undominated. This leaves $* \mathrm{H}$ to penalize the spreading of an input $\mathrm{H}$ onto toneless TBUs. Penalties are assigned by counting $\mathrm{H}$-toned TBUs, not $\mathrm{H}$ autosegments.

${ }^{17}$ While we focus on the constraints that crucially interact for the patterns presented here, we realize a number of other constraints, tangential to our concerns, are also at play e.g. one (in the ANCHOR or ALIGN family) that forces spreading rightward rather than leftward.
} 
$* \mu \mu$<smiles></smiles>

$\mathrm{HH}$

Assign a penalty in each instance where adjacent TBUs are members of distinct High Tone Spans (i.e. are linked to distinct Hs).

The proposed ranking of these four constraints is given below.

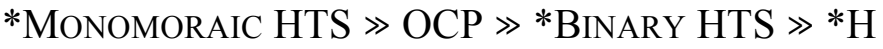

*MonOMORAIC HTS will force a $\mathrm{H}$ to spread, even if it violates the OCP, and therefore must be ranked above OCP. *Binary HTS attempts to spread the H onto a second TBU, but will fail to do so if that would cause an OCP violation and is therefore ranked below OCP. Both *MONOMORAIC HTS and *BINARY HTS force spreading which results in violations of $* \mathrm{H}$. ${ }^{*} \mathrm{H}$ plays an important role in penalizing any spreading not necessary to satisfy the more highly ranked constraints aiming to ensure ternary spread. We now exemplify the constraint interaction in the schematic tableaux below.

We first consider the case of full ternary spreading. This is schematized in (41) where a $\mathrm{H}$ in a nonphrase-final word undergoes ternary spreading (illustrated in (2)).

\begin{tabular}{|c|c|c|c|c|}
\hline $\mathrm{Cr} C v \mathrm{CvCvCv})_{\mathrm{W}}(\mathrm{Cv} \ldots$ & *MONO & $\mathrm{OCP}$ & $* \mathrm{BIN}$ & $* \mathrm{H}$ \\
\hline $\mathrm{Cr} \mathrm{CvCvCvCv}$ & $* !$ & & & $*$ \\
\hline b. $\quad \mathrm{Cú}_{\mathrm{C}} \mathrm{C} \mathrm{Cv} \mathrm{CvCv}$ & & & $* !$ & $* *$ \\
\hline c. $\mathrm{C} \dot{\mathrm{v}} \mathrm{C} \dot{\mathrm{C}} \mathrm{C} \mathrm{C} \mathrm{CvCv}$ & & & & $* * *$ \\
\hline d. $\quad$ CúCúCúCúCv & & & & $* * * * !$ \\
\hline
\end{tabular}

In (41), the correct surface form is the one in which the only (and therefore rightmost) $H$ in the input undergoes Bounded Spreading (ternary in this case) because it does not occur in a p-phrase final word. Candidate (a) is maximally faithful, but violates *MONO which insists that the $\mathrm{H}$ undergo some spreading so as not to surface as a HTS of a single TBU. Candidate (b) satisfies *MonO, but as a HTS comprising exactly two TBUs, violates *BIN. Candidate (c), the optimal one, where the $\mathrm{H}$ has spread to the following two morae, avoids both *MONO and *BIN violations. This is also true of candidate (d), but (c) is preferred over (d) as the former violates $* \mathrm{H}$ less egregiously, as the spreading in (c) is the minimum necessary to satisfy the more highly ranked constraints.

The tableau below illustrates the configuration that results in a phonetic downstep between syllables (data shown in (10)).

\begin{tabular}{|c|c|c|c|c|}
\hline CúCvCŕ & *MONO & $\mathrm{OCP}$ & $* \mathrm{BIN}$ & $* \mathrm{H}$ \\
\hline a. $\quad \mathrm{C} \dot{\mathrm{V}} \mathrm{CvCV}$ & $* * !$ & & & $* *$ \\
\hline b. $\mathrm{C} \mathrm{v}^{\prime} \mathrm{C} \mathbf{v}^{\prime} \mathrm{C} \mathrm{v}$ & $*$ & * & $*$ & $* * *$ \\
\hline
\end{tabular}


The input in (42) has an underlying High-Toneless-High sequence. The faithful candidate (a) violates *MONO since the first $\mathrm{H}$ has not undergone any spreading. In candidate (b), the word-initial $\mathrm{H}$ has undergone spreading to the following TBU, satisfying *MONO. While this candidate violates the OCP, this penalty is not as egregious as the *MoNO one, and therefore (b) is optimal. ${ }^{18}$

Finally, we consider forms where two toneless TBUs intervene between two Hs (illustrated in (11)).

\begin{tabular}{|c|c|c|c|c|}
\hline CŕCvCvCŕ & *MONO & OCP & $* \mathrm{BIN}$ & $* \mathrm{H}$ \\
\hline a. $\mathrm{C} \dot{\mathrm{C}} \mathrm{CvCvCv}$ & $* * !$ & & & $* *$ \\
\hline 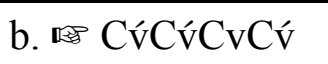 & $*$ & & $*$ & $* * *$ \\
\hline c. $\quad \mathrm{Cú} C \hat{\mathrm{v}} \mathrm{C} \hat{v}^{\prime} \mathrm{C} \mathrm{v}$ & * & $* !$ & & $* * * *$ \\
\hline
\end{tabular}

The faithful candidate (a) violates *Mono as the $\mathrm{H}$ has not spread. Candidate (b), where the $\mathrm{H}$ has spread to just the following TBU, violates *BIN but not the OCP. Candidate (c) where the H has spread two TBUs to the right satisfies both *MONO and *BIN, but violates the OCP. Candidate (b), which is optimal, is accounted for by ranking OCP above *BIN but below *MONO.

Let us now turn to Unbounded Spreading. We account for Unbounded Spreading by positing a constraint that penalizes a p-phrase-final toneless TBU, as formalized in (44). This constraint will force the phrase-final TBU to surface as $\mathrm{H}$. Since we assume that both MAX-H and IDENT-H constraints are undominated in $\mathrm{CB}$, satisfaction of this constraint will never result in a $\mathrm{H}$ being added, or an input $\mathrm{H}$ being displaced to the phrase-final TBU. Thus, it will have no effect on phrases with no $\mathrm{H}$, nor will it have any discernable effect on phrases in which the phrase-final TBU is already $\mathrm{H}$. But in a phrase where the p-final TBU in the input is toneless and there is a $\mathrm{H}$ on some other TBU within the phrase, this constraint compels that $\mathrm{H}$ to become multiply-linked up to and including the phrase-final TBU.

(44) *P-FINAL-L

*(M) $)_{\mathrm{P}}$

Assign a penalty to any p-phrase-final toneless TBU

The effects of this constraint are illustrated in the tableau below.

(45) Unbounded Spreading to the end of a word (as in (1))

\begin{tabular}{|c|c|c|c|c|}
\hline $\mathrm{Cv}(\mathrm{CvCvCv})_{\mathrm{P}}$ & *MONO & *BIN & *P-FIN-L & $* \mathrm{H}$ \\
\hline a. $\mathrm{Cr} C \mathrm{CvCvCv}$ & $* !$ & & $*$ & $*$ \\
\hline b. $\mathrm{C} v \dot{\mathrm{v}} \mathrm{v} \mathrm{Cv} \mathrm{Cv}$ & & $* !$ & $*$ & $* *$ \\
\hline c. $\mathrm{C} v \dot{\mathrm{v}} \mathrm{v} \mathrm{V} \mathrm{C} \dot{\mathrm{v}} \mathrm{Cv}$ & & & $* !$ & $* * *$ \\
\hline 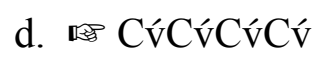 & & & & $* * * *$ \\
\hline
\end{tabular}

\footnotetext{
${ }^{18}$ Again, one can imagine other candidates, requiring additional constraints which are only tangentially relevant to the main points being made here. E.g. a candidate with three level $\mathrm{H}$ tones (with no downstep) would need to be ruled out by a UNIFORMITY constraint that penalizes fusion of non-adjacent Hs.
} 
The fully faithful candidate in (a) violates *MonO. The candidate in (b) where the $\mathrm{H}$ has spread over one TBU, creating a binary HTS, violates *BIN. While candidate (c) satisfies both *MONO and *BIN, it violates *PFINAL-L as the final TBU is not H. Candidate (d) is optimal as it satisfies this constraint, even at the expense of more violations of more lowly ranked $* \mathrm{H}$.

Having illustrated how these constraints work at the word level, we are ready to move to phrases. First, we must account for Inter-word Doubling illustrated in (5), (6) and (8), where the H on a word-final TBU of one word spreads onto the first TBU of the following word. We account for this by positing the domain juncture constraint below in (46) which penalizes a configuration where the final TBU of one word is High and the initial TBU of the following word is toneless. ${ }^{19}$

\section{*INTER-Word HL}

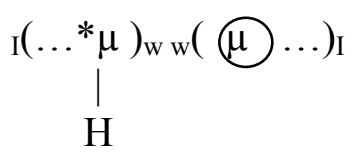

With regard to the prosodic domain that both TBUs must belong to, the process of Inter-Word Doubling was seen to operate over a word boundary in (5), (6) and (8), and over a phonological phrase boundary in (31) and (32). The minimal tonal pairs of phrases in (47) and (48) below show that while this process does in fact operate across a phonological phrase juncture, it does not operate across an intonational phrase juncture - i.e. the two TBUs in question must belong to the same intonational phrase (i-phrase henceforth). For that reason we formulate *INTER-WORD HL as a domain-juncture constraint, introduced as one of three types of phrasal rules in Selkirk 1980, where the larger domain is indicated by the outer brackets. We take up this issue again below.

(47) a. ùmú-límí)P P(tú-ká-pát-á

b. ùmú-límí) I I(tù-kà-pàt-à

(48) a. cùùlá) $P$ P(tú-ká-pát-á

b. cùù́á) I (tù-kà-pàt-à 'the farmer we will hate' (contrastive focus) /úmu-limi tu-ka-pat-a/ 'as for the farmer, we will hate (him)' (topic) /úmu-limi tu-ka-pat-a/

'the frog we will hate' (contrastive focus) /cuulá tu-ka-pat-a/ 'as for the frog, we will hate (it)' (topic) /cuulá tu-ka-pat-a/

In (47a) the object NP is contrastively focused by being pre-posed to the left of the verb. Additional examples of this construction were given in (28). In rule-based terms, the preprefix $\mathrm{H}$ undergoes Unbounded Spreading to the end of the word, which feeds Inter-Word Doubling, which in turn feeds Unbounded Spreading again. In (47b), however, the pre-posed object is topicalized. Here we assume the word is part of a different intonational phrase from the word that follows. This is supported not only by the lack of spreading of the $\mathrm{H}$, but that there is an audible pause between the two words. In this case, while the preprefix $\mathrm{H}$ does undergo Unbounded Spreading (as it is p-phrase final), Inter-Word Doubling does not apply since the two words are not part of the same i-phrase. The examples in (48) show that even when the $\mathrm{H}$ is underlyingly word-final, it will only spread onto the initial TBU of the following word if the two words belong to the same i-phrase (48a), but not if they belong to separate i-phrases (48b).

The *INTER-WORD HL constraint is illustrated in the tableau below, where a High in one word spreads onto the initial TBU of the following word, but no further.

\footnotetext{
${ }^{19}$ See also a similar formulation of a domain juncture constraint for ATR harmony (*INTER-WoRD [-atr][+atr]) in Kügler (this volume).
} 


\begin{tabular}{|c|c|c|}
\hline$(\mathrm{C} v ́ \mathrm{Cv} \quad \mathrm{CvCvCvCv́})_{\mathrm{P}}$ & *MONO & ${ }^{*} \mathrm{I}-\mathrm{W}$ HL \\
\hline a. $\mathrm{C} v \dot{\mathrm{Cv}} \mathrm{CvCvCvCr}$ & $* ! *$ & \\
\hline b. $\mathrm{C} v ́ \mathrm{C} v ́ \mathrm{CvCvCvCŕ}$ & * & $* !$ \\
\hline 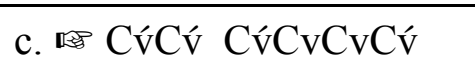 & * & \\
\hline
\end{tabular}

While all candidates violate *MONO because the word-final $\mathrm{H}$ in the second word has no place to spread, the candidate in (49a) violates this constraint a second time since the $\mathrm{H}$ in the first word has not spread. Candidate (b) where the $\mathrm{H}$ has spread just one TBU to the right onto the word-final TBU, will violate *INTERWORD HL since the word-initial TBU of the following word is toneless. Candidate (c) where spreading has reached into that word-initial TBU is therefore optimal.

We now need a way to account for the long-distance spreading patterns seen in (24)-(30) and (31)-(32). Specifically, in a $\mathrm{W}_{1} \mathrm{~W}_{2}$ sequence where there is a single $\mathrm{H}$ in $\mathrm{W}_{1}$ and no $\mathrm{H}$ in $\mathrm{W}_{2}$, we must ensure that the $\mathrm{H}$ in $\mathrm{W}_{1}$ undergoes Bounded Spreading when the first word is not itself final in a p-phrase (50a), but Unbounded Spreading to the end of $\mathrm{W}_{2}$ when the words are part of different $\mathrm{p}$-phrases (50b).
a. (CúCvCvCv $\mathrm{CvCvCvCv)}$
$\rightarrow \quad \mathrm{CúCúCŕCv} \mathrm{CvCvCvCv}$
E.g. (20)-(23) or $(\mathrm{Cr} \mathrm{CvCvCv}(\mathrm{CvCvCvCv}))$
b. $(\mathrm{Cr} \mathrm{CvCvCv})(\mathrm{CvCvCvCv})$
$\rightarrow \quad$ CúCúCúCú CúCúCúCv́
E.g. (24)-(30), (31)-(32)

We propose to account for this difference by positing a second domain-juncture constraint. This one penalizes spreading between two words belonging to the same p-phrase. As we will show below, this constraint will penalize phrases of the type in (50a), but not those of the type in (50b). It is formalized below.

\section{(51) CRISP EdGe}

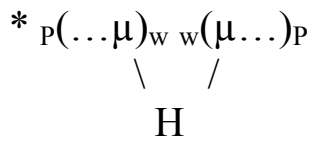

This constraint is a member of the Crisp Edge type, as proposed by Ito \& Mester (1999), and employed by Selkirk (2011), which insists that some feature not be shared across a prosodic juncture (demanding instead that it be crisply aligned with a single edge of a prosodic domain). If ranked above *P-FINAL-L, this CRISP EDGE constraint will block Unbounded Spreading in cases such as (50a) where the spreading would generate the illicit structure formalized in (51). This is illustrated in the tableau below. 
(52) Two words part of the same p-phrase: Bounded (ternary) Spreading of $\mathrm{H}$

\begin{tabular}{|c|c|c|c|c|}
\hline$(\mathrm{CúCvCvCv} \mathrm{CvCvCvCv})_{\mathrm{P}}$ & *MONO & *BIN & CRISP-E & *P-FIN-L \\
\hline a. $\quad(\mathrm{Cú} \mathrm{CvCvCv} \mathrm{CvCvCvCv})$ & $* !$ & & & * \\
\hline b. (CúCúCvCv CvCvCvCv) & & $* !$ & & $*$ \\
\hline c. $(\mathrm{C} v \dot{\mathrm{v}} \mathrm{v} \mathrm{C} v \dot{\mathrm{C}} \mathrm{v} \mathrm{CvCvCvCv})$ & & & & * \\
\hline d. (CúCúCúCú CúCúCúCú) & & & $* !$ & \\
\hline
\end{tabular}

The faithful candidate in (a) violates *MonO, while (b) violates *BIN. The candidate in (d), where the H has spread to the very end of the phrase, is the only one which satisfies *P-FINAL-L. But this spreading violates CRISP-EDge since a single $\mathrm{H}$ is linked to TBUs of two words belonging to the same p-phrase. The optimal candidate in (c), where the spreading is ternary, violates *P-FINAL-L, but satisfies CRISP-E, which is more highly ranked.

Of course, CRISP EDGE will be violated by the optimal candidate in cases such as (49), where an input $\mathrm{H}$ on the penult or ultima spreads into the following word (even when the two words are part of the same pphrase). We account for this by ranking *INTER-WORD HL above CRISP EDGE, as shown in the tableau below.

\begin{tabular}{|c|c|c|c|}
\hline$(\mathrm{Cv́} \mathrm{Cv} \mathrm{CvCvCvCŕ})_{\mathrm{P}}$ & $* \mathrm{MONO}$ & ${ }^{*} \mathrm{I}-\mathrm{W}$ HL & CRISP-E \\
\hline a. ( $\mathrm{Cr} \mathrm{Cv} \mathrm{CvCvCv} \mathrm{Cr})$ & $* * !$ & & \\
\hline b. (CúCŕ CvCvCvCŕ) & $*$ & $* !$ & \\
\hline 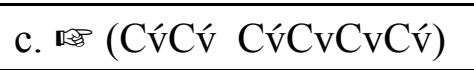 & * & & $*$ \\
\hline
\end{tabular}

The candidate in (b) where the $\mathrm{H}$ has undergone binary spreading, violates *I-W HL, but not CRISP EDGE. Candidate (c) where the $\mathrm{H}$ has spread to the initial TBU of the following word, violates CRISP EDGE, but not the more highly ranked $* \mathrm{I}-\mathrm{W}$ HL.

Let us now examine the form in (50b) where the $\mathrm{H}$ must spread to the end of the entire utterance. It was examples such as this, presented and discussed at the end of section 2, which motivated the iterative mutuallyfeeding rules in the derivational account.

(54) Two words part of different p-phrases: Unbounded Spreading of $\mathrm{H}$

\begin{tabular}{|c|c|c|c|c|c|}
\hline$(\mathrm{Cr} C v \mathrm{CvCv})_{\mathrm{P}}(\mathrm{CvCvCvCv})_{\mathrm{P}}$ & *MONO & $* \mathrm{BIN}$ & $* \mathrm{I}-\mathrm{W} \mathrm{HL}$ & CRISP-E & $*$ P-FIN-L \\
\hline a. $(\mathrm{Cr} C v \mathrm{CvCv})(\mathrm{CvCvCvCv})$ & $* !$ & & & & $* *$ \\
\hline b. $\left(\mathrm{Cr} C \mathrm{Cu}^{\mathrm{CvCv}}\right)(\mathrm{CvCvCvCv})$ & & $* !$ & & & $* *$ \\
\hline c. $(\mathrm{C} v ́ \mathrm{C} v ́ \mathrm{C} v \dot{\mathrm{Cv}})(\mathrm{CvCvCvCv})$ & & & & & $* ! *$ \\
\hline d. (Cv́Cv́Cv́Cv́) ( $\mathrm{CvCvCvCv)}$ & & & $* !$ & & $*$ \\
\hline e. (CúCúCv́Cú) ( $\mathrm{C} \dot{\mathrm{C}} \mathrm{CvCvCv})$ & & & & & $*$ \\
\hline 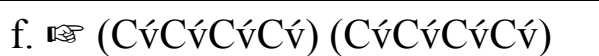 & & & & & \\
\hline
\end{tabular}

Candidates (a) and (b) both violate the highest ranking constraints which force spreading to at least two additional TBUs. Candidate (c) incurs two violations of *P-FIN-L since there are two p-phrase-final TBUs in this utterance and both are toneless. Candidate (d) spreads to the end of the first word (and p-phrase), thus incurring only a single *P-FIN-L violation, but incurs a * I-W HL violation. Candidate (e) spreads the $\mathrm{H}$ one 
TBU further, onto the initial TBU of the second word. This avoids the *I-W HL violation, but it still violates *P-FIN-L as the second phrase-final TBU is not H-toned. Candidate (f), the optimal one, satisfies *P-FIN-L since each of the two p-phrase-final TBUs in the utterance are H-toned. Crucially, CRISP-EDGE is not violated in (f). This is because even though the $\mathrm{H}$ has spread from the first word into the second, CRISP-EDGE was specifically formalized to penalize this only if the two words in question are part of the same phonological phrase. In (f) (as well as (e)), however, the words are part of different p-phrases, and therefore no penalty is assigned.

It should be evident that even in much longer utterances, such as the one in (32d), if each word constitutes its own p-phrase, then the optimal candidate will be the one that spreads a $\mathrm{H}$ to the very end of the entire utterance as this will completely satisfy *P-FIN-L, and not incur any CRISP-EDGE penalty. In this respect the derivational account does seem to be driven by slightly different factors than the OT one. In the derivational account, the two rules which accounted for this long-distance spreading were: 1) Unbounded Spreading, a word-level process that spreads a $\mathrm{H}$ to the end of a word, and 2) Inter-Word Doubling, which spreads a $\mathrm{H}$ from the final TBU of one word onto the initial TBU of the following word. The most direct analogs to these two rules in the OT account are *P-Final L and *Inter-Word HL. While *P-Final L certainly motivates Unbounded Spreading to an often distant TBU, it is less clear that *Inter-Word HL is what forces spreading beyond the end of the first p-phrase, when another (single word) p-phrase follows. It certainly ends up preventing the spreading from stopping right on the final TBU of the first p-phrase, but, as seen in $(54 \mathrm{e})$, does not play a role in preventing the spread from stopping within the following single-word p-phrase. Ultimately this is prevented by *P-FIN-L. CRISP-E, as it has been formalized, ultimately determines, in a string of adjacent words, whether the spreading of the $\mathrm{H}$ in the first word will undergo Unbounded Spreading or Bounded Spreading. But in a configuration such as the one in (54), it plays no role in determining where the spreading will stop. Thus, it seems that *P-FIN-L is really doing the work of forcing long-distance spreading in the OT account. In summary, were the particular OT analysis presented here cast into derivational terms, it would be that a $\mathrm{H}$ tone looks to find the most distant toneless p-phrase final TBU it can spread to (where all intervening TBUs are toneless) where that doesn't involve spreading over two words which are part of the same p-phrase. Characterized as such, *INTER-WORD HL does not play a crucial role in this long-distance spreading, whereas its rule-based counterpart, Inter-Word Spreading, certainly did.

\section{Domain Juncture Effects in Optimality Theory}

Both the *Inter-Word HL (46) and Crisp Edge (51) constraints proposed above were formulated as domain juncture constraints with both outer and inner prosodic edge boundaries included. Given the fact that there is not much precedent in the OT literature for such constraints, we now ask whether two sets of prosodic boundaries are in fact needed, or if the outer set could be dispensed with.

Let us begin with the *Inter-Word HL constraint. We noted above that this constraint accounts for the fact that spreading of a $\mathrm{H}$ across a word boundary takes place between two words when those words are part of the same intonational phrase, but not when the words are part of distinct intonational phrases. While the domain juncture style formulation in (46) captures this, it would also be possible to account for the same tone patterns by using a *Inter-Word HL constraint without the outer intonational phrase specification, in tandem with an additional Crisp Edge constraint which prevented spreading of a $\mathrm{H}$ from the final $\mathrm{TBU}$ of one intonational phrase into another intonational phrase. These constraints are given below.

*INTER-Word HL<smiles>[VH2]c1ccccc1</smiles> 
$* \mu)_{\mathrm{i} i}(\mu$
$\backslash /$
$\mathrm{H}$

We assume that the *I-W HL constraint as revised in (55) forces a $\mathrm{H}$ on the final TBU of one word to spread into the next word regardless of whether the two words are part of the same p-phrase or i-phrase or not. However, the Crisp Edge constraint in (56) will prohibit such spreading from one intonational phrase into another. When (56) is ranked above (55), then the attested spreading patterns in this regard are accounted for, as illustrated below.

(57)

\begin{tabular}{|c|c|c|c|}
\hline$\left(\mathrm{C} v \mathrm{~V}^{\mathrm{V}}\right)_{\mathrm{P}}(\mathrm{CvCvCvCv})_{\mathrm{P}}$ & *MONO & $\overline{\mathrm{CE}}-\mathrm{H}, \mathrm{i}$ & ${ }^{*} \mathrm{I}-\mathrm{W} \mathrm{HL}$ \\
\hline a. $\mathrm{C} \dot{\mathrm{C}} \mathrm{Cv} \mathrm{CvCvCvCr}$ & $* * !$ & & \\
\hline b. CŕCŕ CvCvCvCŕ & * & & $* !$ \\
\hline 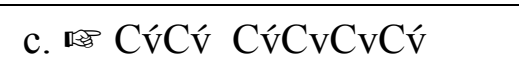 & $*$ & & \\
\hline
\end{tabular}

(58)

\begin{tabular}{|c|c|c|c|}
\hline$(\mathrm{Cv́} C \hat{v})_{\mathrm{I}}(\mathrm{CvCvCvCv́})_{\mathrm{I}}$ & *MONO & CE-H, i & ${ }^{*} \mathrm{I}-\mathrm{W} \mathrm{HL}$ \\
\hline a. CúCv $\mathrm{CvCvCvCv́}$ & $* * !$ & & \\
\hline b. CúCŕ $\mathrm{CvCvCvCv́}$ & * & & $* !$ \\
\hline c. CúCú Cúleveveŕ & * & $* !$ & \\
\hline
\end{tabular}

Having found an alternative to specifying outer edge prosodic boundaries in the *INTER-WORD HL constraint, we now investigate if this might also be possible with regard to the Crisp Edge constraint formalized as a domain-juncture constraint in (51). The constraint was formalized as such so that it would penalize the Unbounded Spreading of a $\mathrm{H}$ in cases such as (59a) where the two words belong to the same phonological phrase, but not to cases such as (59b) where the two words belong to separate phonological phrases.
a. $\left.\mathrm{H} \ldots)_{\mathrm{W}} \mathrm{w}(\ldots)_{\mathrm{W}}\right)_{\mathrm{P}}$
H must not undergo Unbounded Spreading

(either to the end of the word or phrase)

b. $\left.\mathrm{H} \ldots)_{\mathrm{W}}\right)_{\mathrm{P}} \mathrm{P}\left(\mathrm{w}(\ldots)_{\mathrm{W}}\right)_{\mathrm{P}}$

$\mathrm{H}$ must undergo Unbounded Spreading to the end of the word (and if the following word is toneless, to the end of that word as well) (60).

Removing the outer p-phrase brackets of the Crisp Edge constraint as formalized above in (51) yields

(60) CRISP EdGE (revised)

$$
\begin{gathered}
* \mu)_{\mathrm{W} w} \mathrm{w}(\mu \\
\mathrm{H}
\end{gathered}
$$

The revised constraint in (60) will penalize a multiply-linked $\mathrm{H}$ between any two words in sequence regardless of whether the words are members of the same p-phrase or i-phrase. This revised Crisp Edge 
constraint makes the same, correct, predication in the case where the two words are part of the same phonological phrase. It will, e.g. assign the very same penalties that the domain-juncture Crisp Edge constraint in (51) did in cases such as (52) where the two words belong to the same phonological phrase. However, the revised Crisp Edge constraint in (60) makes incorrect predictions when the two words are part of different phonological phrases, as shown below.

(61) Two words part of different p-phrases: Unbounded Spreading of $\mathrm{H}$

\begin{tabular}{|c|c|c|c|c|c|}
\hline 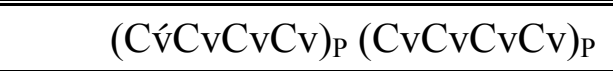 & $*$ MONO & $* \mathrm{BIN}$ & *I-W HL & CE (REV) & $*$ P-FIN-L \\
\hline a. $(\mathrm{Cr} C v \mathrm{CvCv})(\mathrm{CvCvCvCv})$ & $* !$ & & & & $* *$ \\
\hline b. $(\mathrm{C} \dot{\mathrm{C}} \mathrm{C} \dot{\mathrm{C}} \mathrm{Cv} \mathrm{Cv})(\mathrm{CvCvCvCv})$ & & $* !$ & & & $* *$ \\
\hline 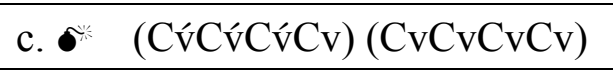 & & & & & $* ! *$ \\
\hline d. $(\mathrm{C} v \dot{\mathrm{C}} \mathbf{\mathrm { C }} \mathrm{C} \dot{\mathrm{C}} \mathrm{v})(\mathrm{CvCvCvCv})$ & & & $* !$ & & $*$ \\
\hline 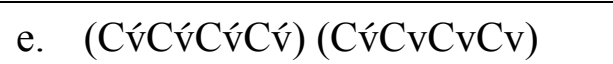 & & & & $*$ & $*$ \\
\hline 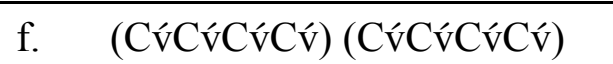 & & & & $*$ & \\
\hline
\end{tabular}

As can be seen above, if Crisp Edge, as revised in (60), penalizes the spreading between any two words, then it will assign a penalty to candidates (61e) and (61f), but not to candidate (61c). This ultimately selects candidate (61c) which exhibits ternary but not Unbounded Spreading, to be optimal, but it is not. Given the fact that Crisp Edge must be ranked above *P-Final L (required in (52)), it is not clear to us what other constraint could be invoked which, ranked above the revised Crisp Edge constraint in (60), would penalize (61c), while not also penalizing (61f).

We therefore conclude here that while the *INTER-WORD HL constraint can in fact be formalized without resorting to the domain-juncture style formulation which necessitates both an outer and inner domain specification, the Crisp Edge constraint in (51) does seem to necessitate both domains in its formalization.

\section{Summary and Conclusion}

In this paper, we have described a wide array of phrasal tone spreading patterns in Copperbelt Bemba. When a word has more than one High tone, all Hs before the final one undergo Bounded (ternary) Spreading. What is interesting is the spreading pattern of the rightmost $\mathrm{H}$ in a word. In some cases it undergoes Bounded Spreading, while in other cases it undergoes Unbounded Spreading. We have demonstrated that this choice is strictly determined by the prosodic phrasing. In a $\mathrm{W}_{1} \mathrm{~W}_{2}$ sequence, the rightmost $\mathrm{H}$ in $\mathrm{W}_{1}$ will undergo Bounded Spreading if $\mathrm{W}_{1}$ and $\mathrm{W}_{2}$ are part of the same phonological phrase, but it will undergo Unbounded Spreading if the two words are part of different phonological phrases, i.e. when the first word is phonological phrase final. We showed that the location of these phonological phrase boundaries correspond to the right edges of maximal projections of lexical phrases. This is consistent with the range of predicted possible phrasings by current OT-based theories of the syntax-phonology interface, such as ALIGN/WRAP XP and Match Theory. In a rule-based approach the two processes of Unbounded Spreading and Inter-Word Doubling turn out to stand in an iterative mutually-feeding relationship. Thus given a string of words, each of which comprises a single pphrase, a $\mathrm{H}$ in the first word will spread through the whole string of toneless words to the final TBU.

In addition to a *P-FINAL Low constraint which accounts for Unbounded Spreading to the end of phonological phrases, a second phrasal constraint, *INTER-WORD HL, accounts for a process whereby a H on the final mora of a word will double onto the initial mora of the following word. We then presented two possible analyses which prevent such spreading from occurring across intonational phrases. Unbounded Spreading of a $\mathrm{H}$ from one word to the following one must be prevented when the two words belong to the same phonological phrase. This is accomplished with a CRISP EDGE constraint. We endeavored to show, 
however, that in order for the constraint to only penalize spreading between words belonging to the same phonological phrase, it must be formalized as a domain juncture type of constraint in which two prosodic domains are specified.

References:

Bickmore, L. (1999) High Tone Spread in Ekegusii Revisited: An Optimality Theoretic Account. Lingua 109: 109-153.

Bickmore, L. (2007) Cilungu Phonology. Stanford: Center for the Study of Language and Communication.

Bickmore, L. \& N.C. Kula (2013) Ternary Spreading and the OCP in Copperbelt Bemba. Studies in African Linguistics 42 (2): 101-132

Bresnan, J. \& S. Mchombo (1987) Topic, pronoun and agreement in Chichewa. Language 63: 741-782.

Cassimjee, F. \& C. Kisseberth (1998) Optimal Domains Theory and Bantu Tonology: A case study from Isixhosa and Shingasidja. In Larry Hyman and Charles Kisserbeth (eds.) Theoretical Aspects of Bantu Tone. Stanford, CA: CSLI Publications, 33-132.

Dehe, N., I. Feldhausen \& S. Ishihara (eds.) (2010) Special issue on The Phonology-Syntax Interface. Lingua 121(13).

Inkelas, S. \& D. Zec (eds.) (1990) The Phonoogy-Syntax Connection. Chicago: Chicago University Press.

Ito, J., \& A. Mester (1999) Realignment. In René Kager, Harry van der Hulst and Wim Zonnefeld (eds.) The Prosody-Morphology Interface. Cambridge: Cambridge University Press, 188-217.

Kaisse, E.M. (1985) Connected Speech: The Interpretation of Syntax and Phonology. Orlando: Academic Press.

Kisseberth, C. (1994) On Domains. In Jennifer Cole \& Charles Kisseberth (eds.) Perspectives in Phonology. Stanford, CA: CSALI Publications, 133-166.

Kula, N.C (2007) Effects of phonological phrasing on syntactic structure. The Linguistic Review 24(2): 201231.

Marten, L., Kula N.C. \& N. Thwala (2007) Parameters of morphosyntactic variation in Bantu. Transactions of the Philological Society 105(3): 253-338.

Marten, L. \& N.C. Kula (2012): Object marking and morphosyntactic variation in Bantu. Southern African Linguistics and Applied Language Studies 30(2): 237-253.

Marten, L. \& N.C. Kula (2014) Benefactive and substitutive applicatives in Bemba. Journal of African Languages and Linguistics 35(1): 1-44.

McCarthy, J. (2004). Headed spans and autosegmental spreading. Ms. University of Massachusetts, Amherst [ROA-685].

McCarthy, J. \& A. Prince (1995) Generalized Alignment. Yearbook of Morphology, 79-153.

McHugh, B. 1990. The phrasal cycle in Kivunjo Chaga tonology. In S. Inkelas \& D. Zec (eds.) The PhonologySyntax Connection. Chicago: The University of Chicago Press, 217-242.

Morimoto, Y. (2005) Discourse configurationality and discontinuous NPs in Chichewa. In Kula, N.C \& R. Letsholo (eds.) African Linguistics in the New Millennium. Special issue of Linguistic Analysis 32: 437470 .

Nespor, M. \& I. Vogel (1986) Prosodic Phonology. Dordrecht: Foris.

Odden, D. (1986) On the role of the obligatory contour principle in phonology. Language 62: 353-383.

Scheer, T. (2012) Direct Interface and One-channel Translation. Berlin/New York: Mouton de Gruyter.

Sharman, J.C. \& A.E. Meeussen (1955) The representation of structural tones, with special reference to the tonal behaviour of the verb, in Bemba, Northern Rhodesia. Africa 25: 393-404.

Selkirk, E. (1980). Prosodic domains in phonology: Sanskrit revisited. In Mark Aronoff \& Mary-Louise Kean (eds.) Juncture. Saratoga, CA: Anma Libri.

Selkirk, E. (1986). Phonology and Syntax: The Relation Between Sound and Structure. Cambridge: MIT Press.

Selkirk, E. (1995). The prosodic structure of prosodic words. University of Massachusetts Occasional Papers 18: Papers in Optimality Theory: 439-469. GLSA, University of Massachusetts, Amherst. 
Selkirk, E. (2011) The Syntax-Phonology Interface. To appear in John Goldsmith, Jason Riggle and Alan Yu (eds.) The Handbook of Phonological Theory, 2nd edition, Oxford: Blackwell Publishing.

Truckenbrodt, H. (1999) On the relation between Syntactic Phrases and Phonological Phrases. Linguistic Inquiry 30(2): 219-255.

Vincent N. \& L. Mycock (eds.) (2010) Special issue on The Prosody-Syntax Connection. Transactions of the Philological Society 108(3).

Yip, M. (2002). Tone. Cambridge: Cambridge University Press. 